\title{
MICROBIOLOGICAL INVESTIGATIONS OF SOME DRIED MIXES OF DAIRY DESSERTS SOLD IN ASSIUT CITY
}

\author{
M.N. EL-GENDI MARWA and M.T.A. EL-SHREEF LAMIAA \\ Animal Health Research Institute, Assiut Regional Laboratory.
}

\section{ABSTRACT}

Received at: 31/3/2013

Accepted: 19/5/2013
The research work was aimed to evaluate the microbiological quality of dried mixes of dairy products highly consumed by the public in Egypt. To verify the quality and safety of these products, 90 random samples of whipped cream; chocolate pudding powder and sauce (all in powder form and main component is milk powder either full or skimmed milk powder and other components differ in each product) were collected from different manufactures. These products examined for total bacterial count (average counts were $8.72 \times 10^{4} ; 9.29 \times 10^{4}$ and $1.29 \times 10^{5} \mathrm{cfu} / \mathrm{g}$ in examined samples of cream, chocolate pudding and sauce respectively). While, total thermophillic count were detected in examine samples of whipped cream and chocolate and failed to be counted in sauce samples. In addition, the total coliforms counts and total yeasts and molds counts were recorded. Also, the examination of these products for contamination by some pathogenic microorganisms were done and revealed that E. coli O157:H7 and coagulase positive S. aurous could not be isolated from all examined samples. While listeria monocytogenes could be isolated from chocolate pudding in percentage of $26.7 \%$. The microbial population detected in terms of numbers and types of microorganisms reflect the poor hygienic standard of production which constituting a public health hazard.

Key words: Dairy desserts, Total coliform count, public health hazard.

\section{INTRODUCTION}

Milk desserts are popular products worldwide, usually formulated with milk, sugar, modified starch, hydrocolloids such as carrageenans, flavorings and colorants (DeWijk et al., 2003 and González-Tomás and Costell, 2006). Whipped toppings have become popular both for commercial and consumer use on puddings, sodas, cakes, ice cream, fruits, and pastries and for cream pie bases. The importance of dairybased foods as vehicle for the transmission of various diseases has been documented; especially in countries where hygienic standards are not strictly enforced (Meyer-Broseta et al., 2003). Contaminated milk and its by-products may harbor a variety of microorganisms which are responsible for many food-borne outbreaks (Danielsson-Tham et al., 2004; MacDonald et al., 2005; Makino et al., 2005; Okwumabua et al., 2005 and Oliver et al., 2005).

Dried skim milk products stored in optimal conditions in proper packaging show essentially no change in color, even during two years of storage at $35^{\circ} \mathrm{C}$. In commercial situations, most dried milk products are susceptible to reactions that can result in small changes in the physical properties of the product, its palatability and nutritive value. These changes, however, do not significantly impact the nutritional benefits of milk powders. Vitamin and protein quality losses during storage of milk powders, when stored in good conditions, are negligible (U.S. Dairy Export Council, 2001).

Likewise, the quality of food depends on the total number of viable organisms as revealed by the total bacterial count. However, the microbial load of food products is influenced by a number of factors such as the general environment from which the raw materials were obtained, the environment in which it was processed, the sanitary conditions under which the food was handled and processed, and the adequacy of processing procedures targeted at reducing contaminants during the packaging, handling and storage of the product (Osamwonyi, 2005).

The thermophilic bacilli are an important group of contaminants in the dairy industry. Although these bacilli are generally not pathogenic, their presence in dairy products is an indicator of poor hygiene and high numbers are unacceptable to customers. In addition, their growth may result in milk product 
defects caused by the production of acids or enzymes, potentially leading to off-flavours. Dairy thermophiles are usually selected for the conditions during dairy manufacture. These bacteria are able to grow in sections of dairy manufacturing plants where temperatures reach $40-65{ }^{\circ} \mathrm{C}$. Furthermore, because they are spore formers, they are difficult to eliminate. In addition, they exhibit a wide temperature growth range, exhibit a fast growth rate (generation time of approximately $15-20 \mathrm{~min}$ ) and tend to readily form biofilms (Burgess et al., 2010).

Coliforms being non-spore formers should be susceptible to pasteurization. Their post pasteurization presence in the examined samples may be due to either faulty heat process or to post pasteurization contamination by handlers with poor sanitary practices. The presence of these organisms in food had been described as an index of food hygiene (Frazier and Westhoff, 1978 and Jay, 1978).

Even though food-borne $S$. aureus poisoning is a mild, generally self-limiting disease, with symptoms that include vomiting with or without diarrhea (Dinges et al., 2000), hospitalization is required in approximately $10 \%$ of the cases (Holmberg and Blake, 1984).

Moreover Listeria is considered to be one of the most important causes of food-borne diseases. $L$. monocytogenes, a ubiquitous gram-positive microaerophilic bacterium, is capable of causing severe listeriosis infections in humans (encephalitis, meningitis and septicaemia especially in immunocompromised individuals) and animals (mastitis, diarrhea and gastroenteritis) (Herman et al., 1995; Vela et al., 2001; Siegman-Igra et al., 2002; McLauchlin et al., 2004 and Aygun and Pehlivanlar, 2006). L. monocytogenes has been involved in many outbreaks and sporadic cases of disease primarily associated with the consumption of pasteurized milk, cheeses made from unpasteurized milk and other dairy based products that serve as good medium for the growth and survival of many pathogenic organisms in both industrialized and developing countries (Kells and Gilmour, 2004; Makino et al., 2005 and Manfreda et al., 2005). Usually, the presence of any Listeria species in food is an indication of microbial contamination (Gilot and Content, 2002).

E. coli O157:H7 (designated by its somatic, O, and flagellar, $\mathrm{H}$, antigens) was first recognized as a human pathogen following two hemorrhagic colitis outbreaks in 1982. Cross-contamination of foods can occur in food-processing plants and during subsequent handling and preparation, resulting in a wide range of foods being implicated in outbreaks of E. coli O157:H7 infections. E. coli serotype O157:H7 is a rare variety of $E$. coli but is a normal inhabitant of the intestines of all animals, including humans. The pathogen produces large quantities of one or more related potent toxins, called Shiga toxins, which cause severe damage to the lining of the intestine and to other target organs, such as the kidneys. The most severe outcome of Shiga toxin exposure among the general population is typically hemorrhagic colitis, a prominent symptom of which is bloody diarrhea. However, life-threatening complications sometimes occur. Some victims, particularly the very young, may develop hemolytic uremic syndrome (HUS). Overall, the Center for Disease Control and Prevention estimates that E. coli O157:H7 is responsible for approximately 73,500 infections, 2150 hospitalizations, and 61 deaths in the United States each year (Saleh et al., 2009; Burgess et al., 2010 and CDC, 2012).

Economically, the presence of yeasts and molds in dairy products are undesirable even when found in few numbers as they rapidly grow in the product in a wide range of temperature, $\mathrm{PH}$ and humidity, resulting in objectionable changes that render the product of inferior quality or even unmarketable. Yeasts and moulds are used as an index of the proper sanitation and quality control for certain dairy products. The public health importance of moulds has been emphasized as certain species can produce mycotoxins at a temperature $2-10{ }^{\circ} \mathrm{C}$, which is implicated in human cases of food poisoning and neoplastic diseases including leukemia and cancers as reported by (Bullerman, 1980 and Mossel, 1982).

The purpose of the present study is to investigate the presence of some bacteria such as E. coli O157:H7; Staph. aureus and Listeria spp in dried mixes of dairy desserts sold in Assiut city. Also, total aerobic plate count, total thermophillic count, total coliforms and total yeast and molds count will be estimated.

\section{MATERIALS and METHODS}

\section{A) Collection, preparation and serial dilutions of samples:}

A total of ninety random samples of whipped cream, chocolate pudding and sauce (all are in powder status, packaged, unpackaged and 30 samples of each product) were purchased from different shops and supermarkets in Assiut city. The samples were still valid for consumption more than one year from production time and they were transferred to the laboratory in their packages to be analyzed microbiologically to evaluate their quality. Eleven grams of the prepared samples were mixed with 99 $\mathrm{ml}$ of sterile $0.1 \%$ peptone water and thoroughly mixed to give a dilution of $1 / 10$, and then ten fold serial dilutions were carried out according to (A.P.H.A., 1992). 
B) Experimental techniques:

1) Enumeration of total bacterial count according to A.P.H.A. (1992) by using standard plate count agar.

2) Enumeration of total thermophillic count at $55^{\circ} \mathrm{C}$ for $48 \mathrm{~h}$ according to Frank and Yousef (2004).

3) Enumeration of total yeasts and molds count according to Harrigan and MacCance (1976) by using malt extract agar (containing $500 \mathrm{mg}$ each of chlortetracycline and HCL chloramphenicol)

4) Enumeration of total coliform count according to Ray and Speck (1978) by using violet red bile glucose agar

\section{5) Isolation and identification of S. aureus:}

S. aureus was isolated by using the technique given by Baird Parker (1962). Enriched samples (A Portion $10 \mathrm{~g}$ ) from each sample was extracted aseptically and homogenized with $90 \mathrm{ml}$ sterile mannitol salt broth) were streaked on Baird Parker Agar (BPA) and the plate was incubated at $37{ }^{\circ} \mathrm{C}$ for $24-48$ hours. Appearances of jet black colonies surrounded by white halo were considered to be presumptive $S$. aureus. Identification of S. aureus by using coagulase test, catalase test, anaerobic utilization of glucose and mannitol and Gram stain.

6) Isolation and identification of $E$. coli o157:H7: For detection of E. coli O157:H7, trypticase soy broth was supplemented with cefixime $(0.05 \mathrm{mg} / \mathrm{l})$, cefsulodin $(10 \mathrm{mg} / \mathrm{l})$ and vancomycin $(8 \mathrm{mg} / \mathrm{l})$ for pre enrichment $\left(37^{\circ} \mathrm{C}\right)$. After the addition of the samples into the modified trypticase soy broth, shakeincubation was performed at $37{ }^{\circ} \mathrm{C}$ the enriched samples were plated onto sorbitol Mac-Conkey agar (SMCA) supplemented with $0.05 \mathrm{mg} / \mathrm{l}$ cefixime and potassium tellurite $(2.50 \mathrm{mg} / \mathrm{l})$ after 4 and 24 hours. Presumptive E.coli O157:H7 colonies (indole positive) were confirmed serologically using antibodies to the $\mathrm{O} 157$ antigen (E.coli O157:H7 latex test, Oxoid DR 260). According to these results, agglutination and indole positive colonies were recognised as E.coli O157 (AOAC, 1998).

7) Isolation and identification of L. monocytogenes: A $25 \mathrm{~g}$ portion of each sample was weighed aseptically into a sterile stomacher bag containing $225 \mathrm{ml}$ of sterilized $1 \%(\mathrm{w} / \mathrm{v})$ peptone water and macerated in a laboratory blender stomacher for 3 min (Peng and Shelef, 2000). A selective medium: Listeria Selective Agar (LSA) (Oxoid, Hampshire, UK) containing Listeria selective supplement (Oxford modified) (Oxoid, Hampshire, UK) was used for the isolation, enrichment and plating of Listeria (Gulmez and Guven, 2003). Bacteriological analyses were performed, by plating in duplicates (a volume of 0.1 $\mathrm{ml}$ of each dilution on agar plates containing appropriate selective media) (Gulmez and Guven, 2003). All analyses were conducted under aseptic conditions. Plated cultures were then incubated at 35 ${ }^{\circ} \mathrm{C}$ for $48 \mathrm{~h}$ (Gulmez and Guven, 2003). Colonies that exhibited the L. monocytogenes morphology were preserved for further analyses. All bacteriological analyses were done according to the Compendium of Methods for the Microbiological Examination of Foods (Downes and Ito, 2001 and Horwitz, 2001).

Biochemical identification of the suspected $L$. monocytogenes isolates:

Colonies appearing on LSA were first selected based on their morphology then identified by biochemical tests. Black to brown colonies surrounded by black halos was chosen (Hitchins, 1995 and Aygun and Pehlivanlar, 2006). Those colonies were Gram stained. Only Gram-positive short rods were further tested for their ability to produce acids from the fermentation of D-xylose and L-rhamnose sugars, and were also subjected to the $\beta$-haemolysis test (Cocolin et al., 2002 and Zhou and Jiao, 2005).

\section{RESULTS}

Table 1: Statistical analytical results of aerobic plate count of the examined samples.

\begin{tabular}{ccccccc} 
Type of sample & $\begin{array}{c}\text { No. of examined } \\
\text { samples }\end{array}$ & \multicolumn{2}{c}{ Positive samples } & \multicolumn{3}{c}{ Counts / g } \\
\cline { 3 - 7 } & & No. & $\%$ & Min. & Max. & Average \\
\hline Whipped cream & 30 & 29 & 96.7 & $>300$ & $7.36 \times 10^{5}$ & $8.72 \times 10^{4}$ \\
\hline Chocolate pudding & 30 & 28 & 93.3 & $>300$ & $6.88 \times 10^{5}$ & $9.29 \times 10^{4}$ \\
\hline Sauce & 30 & 29 & 96.7 & $>300$ & $7.8 \times 10^{5}$ & $1.29 \times 10^{5}$ \\
\hline
\end{tabular}

No.: number of samples 
Assiut Vet. Med. J. Vol. 59 No. 137 April 2013

Table 2: Frequency distribution of positive samples based on their aerobic plate count.

\begin{tabular}{ccccccc}
\hline Counts / g & \multicolumn{2}{c}{ Whipped cream } & \multicolumn{2}{c}{ Chocolate pudding } & \multicolumn{2}{c}{ Sauce } \\
\hline & (No. : 29) & \% & (No. : 29) & \% & (No. : 29) & \% \\
\hline $\mathbf{1 0}-<\mathbf{1 0}^{\mathbf{2}}$ & 4 & 13.8 & 7 & 25 & 4 & 13.8 \\
\hline $\mathbf{1 0}^{\mathbf{2}}-<\mathbf{1 0}^{\mathbf{3}}$ & 7 & 24.2 & 3 & 10.7 & 7 & 24.2 \\
\hline $\mathbf{1 0}^{\mathbf{3}}-<\mathbf{1 0}^{\mathbf{4}}$ & 5 & 17.2 & 6 & 21.4 & 6 & 20.7 \\
\hline $\mathbf{1 0}^{\mathbf{4}}-<\mathbf{1 0}^{\mathbf{5}}$ & 5 & 17.2 & 4 & 14.3 & 4 & 13.7 \\
\hline $\mathbf{1 0}^{\mathbf{5}}-<\mathbf{1 0}^{\mathbf{6}}$ & 8 & 27.6 & 8 & 28.5 & 8 & 27.6 \\
\hline Total & 29 & 100 & 28 & 100 & 29 & 100 \\
\hline
\end{tabular}

Table 3: Statistical analytical results of total thermophillic count of the examined samples:

\begin{tabular}{ccccccc}
\hline \multirow{2}{*}{ Type of samples } & $\begin{array}{c}\text { No. of } \\
\text { examined } \\
\text { samples }\end{array}$ & No. & $\%$ & Mositive samples & \multicolumn{3}{c}{ Count / g } \\
\cline { 3 - 7 } & 30 & 8 & 26.7 & $>10$ & $6.9 \times 10^{2}$ & $8.27 \times 10$ \\
\hline Whipped cream & 30 & 4 & 13.3 & $>10$ & $1.6 \times 10^{2}$ & $1.27 \times 10$ \\
\hline Chocolate pudding & 30 & 0 & 0 & $>10$ & $>10$ & $>10$ \\
\hline Sauce & & & & & & Average \\
\hline
\end{tabular}

Table 4: Frequency distribution of positive samples based on their total thermophillic count.

\begin{tabular}{ccccccc}
\hline \multirow{2}{*}{ Counts / g } & \multicolumn{2}{c}{ Whipped cream } & \multicolumn{2}{c}{ Chocolate pudding } & \multicolumn{2}{c}{ Sauce } \\
\cline { 2 - 7 } & $($ No. : 8$)$ & $\%$ & $($ No. : 4) & $\%$ & No. : : & $\%$ \\
\hline $\mathbf{1 0}-<\mathbf{1 0}^{\mathbf{2}}$ & 2 & 25 & 2 & 50 & 0 & 0 \\
\hline $\mathbf{1 0}^{\mathbf{2}}-<\mathbf{1 0}^{\mathbf{3}}$ & 6 & 75 & 2 & 50 & 0 & 0 \\
\hline Total & 8 & 100 & 4 & 100 & 0 & 0 \\
\hline
\end{tabular}

Table 5: Statistical analytical results of total coliforms count in the examined samples:

\begin{tabular}{ccccccc}
\hline \multirow{2}{*}{ Type of samples } & $\begin{array}{c}\text { No. of } \\
\text { examined } \\
\text { samples }\end{array}$ & \multicolumn{2}{c}{ Positive samples } & \multicolumn{3}{c}{ Count /g } \\
\cline { 3 - 7 } & 30 & 29 & 96.7 & $>100$ & $4.12 \times 10^{5}$ & $6.55 \times 10^{4}$ \\
\hline Whipped cream & 30 & 22 & 73.3 & $>100$ & $4.4 \times 10^{5}$ & $6.67 \times 10^{4}$ \\
\hline Chocolate pudding & 30 & 27 & 90 & $>100$ & $7 \times 10^{5}$ & $1.19 \times 10^{5}$ \\
\hline Sauce & 30 & & & & & Min.
\end{tabular}


$\underline{\text { Assiut Vet. Med. J. Vol. } 59 \text { No. } 137 \text { April } 2013}$

Table 6: Frequency distribution of positive samples based on their total coliforms count.

\begin{tabular}{ccccccc}
\hline \multirow{2}{*}{ Counts / g } & \multicolumn{2}{c}{ whipped cream } & \multicolumn{2}{c}{ Chocolate pudding } & \multicolumn{2}{c}{ Sauce } \\
\cline { 2 - 7 } & $(\mathbf{N o . : 2 9 )}$ & $\boldsymbol{\%}$ & $\mathbf{( N o . : 2 2 )}$ & $\boldsymbol{\%}$ & (No.:27) & $\boldsymbol{\%}$ \\
\hline $\mathbf{1 0}^{\mathbf{3}}-<\mathbf{1 0}^{\mathbf{4}}$ & 4 & 13.8 & 4 & 18.2 & 4 & 14.8 \\
\hline $\mathbf{1 0}^{\mathbf{4}}-<\mathbf{1 0}^{\mathbf{5}}$ & 19 & 65.5 & 11 & 50 & 16 & 59.3 \\
\hline $\mathbf{1 0}^{\mathbf{5}}-<\mathbf{1 0}^{\mathbf{6}}$ & 6 & 20.7 & 7 & 31.8 & 7 & 25.9 \\
\hline Total & 29 & 100 & 22 & 100 & 27 & 100 \\
\hline
\end{tabular}

Table 7: Statistical analytical results of total yeasts and molds count in the examined samples.

\begin{tabular}{ccccccc}
\hline \multirow{2}{*}{ Type of samples } & $\begin{array}{c}\text { No. of } \\
\text { examined } \\
\text { samples }\end{array}$ & \multicolumn{2}{c}{ Positive samples } & \multicolumn{3}{c}{ Count /g } \\
\cline { 3 - 7 } & 30 & 20 & 66.7 & $>10$ & $1.16 \times 10^{4}$ & $1.41 \times 10^{3}$ \\
\hline Whipped cream & 30 & 17 & 56.7 & $>10$ & $1.1 \times 10^{4}$ & $1.11 \times 10^{3}$ \\
\hline Chocolate pudding & 30 & 21 & 70 & $>10$ & $6.2 \times 10^{3}$ & $7.55 \times 10^{2}$ \\
\hline Sauce & & & & &
\end{tabular}

Table 8: Frequency distribution of positive samples based on their total yeasts and moulds count.

\begin{tabular}{ccccccc}
\hline \multirow{2}{*}{ Counts / g } & \multicolumn{2}{c}{ whipped cream } & \multicolumn{2}{c}{ Chocolate pudding } & \multicolumn{2}{c}{ Sauce } \\
\cline { 2 - 7 } & No./20 & \% & No. /17 & \% & No. /21 & \% \\
\hline $\mathbf{1 0}^{-<\mathbf{1 0}^{2}}$ & 7 & 35 & 2 & 11.8 & 11 & 52.4 \\
\hline $\mathbf{1 0}^{\mathbf{2}}-<\mathbf{1 0}^{\mathbf{3}}$ & 8 & 40 & 7 & 41.2 & 4 & 19 \\
\hline $\mathbf{1 0}^{3}-<\mathbf{1 0}^{4}$ & 3 & 15 & 7 & 41.2 & 6 & 28.6 \\
\hline $\mathbf{1 0}^{4}-<\mathbf{1 0}^{\mathbf{5}}$ & 2 & 10 & 1 & 5.8 & 0 & 0 \\
\hline Total & 20 & 100 & 17 & 100 & 21 & 100 \\
\hline
\end{tabular}

Table 9: Incidence of S. aureus; E. coli O157:H7 and L. monocytogenes in the examined samples.

\begin{tabular}{lcccccc}
\hline Microorganisms & \multicolumn{2}{c}{ Whipped cream } & \multicolumn{2}{c}{ Chocolate pudding } & \multicolumn{2}{c}{ Sauce } \\
\hline Products & $($ No.:30) & $\boldsymbol{\%}$ & $\mathbf{( N o . : 3 0 )}$ & $\boldsymbol{\%}$ & $\mathbf{( N o . : 3 0 )}$ & $\boldsymbol{\%}$ \\
\hline S. aureus & 0 & 0 & 0 & 0 & 0 & 0 \\
\hline E. coli & 2 & 6.7 & 0 & 0 & 1 & 3.3 \\
\hline L. monocytogenes & 0 & 0 & 8 & 26.7 & 0 & 0 \\
\hline
\end{tabular}

\section{DISCUSSION}

Data depicted in Table 1. revealed that total aerobic plate count were found in most of the examined whipped cream samples, with a minimum value of $>10 \mathrm{cfu} \mathrm{g}^{-1}$, maximum value of $7.36 \times 10^{5} \mathrm{cfu} \mathrm{g}^{-1}$ and a mean value of $8.72 \times 10^{4} \mathrm{cfu} \mathrm{g}^{-1}$. Also, it is found that $96.7 \%$ of sauce samples had total aerobic plate count ranged from $>10$ to $7.8 \times 10^{5}$ with an average count $1.29 \times 10^{5}$. While, chocolate pudding had an average count $9.29 \times 10^{4}$. The majority of the positive samples of three examined products occurred between $10^{5}-<$ $10^{6}$ (Table 2). The results obtained in our study showed that most of the samples tested positive for aerobic plate counts which are indicators of aerobic bacteria. This finding may reflect the absence of strict hygienic practices in the preparation of those products. A high aerobic plate count level, in general, is indicative of the possible presence of harmful microorganisms and makes the food unsatisfactory 
for human consumption (Gilbert et al., 2000 and Gillespie and Little, 2000).

Total thermophillic counts were detected in 8 and 4 samples of whipped cream and chocolate pudding in percentage of $26.7 \%$ and $13.3 \%$, respectively. Sauce samples found to be uncontaminated with thermophillic bacteria (Table 3). Table, 4 revealed that the $75 \%$ of the positive samples of filling cream occurred between $10^{2}$ to $<10^{3}$. In addition, $50 \%$ of the positive samples of chocolate pudding harbor thermphillic bacteria between $10^{2}-<10^{3} \mathrm{cfu} \mathrm{g}^{-1}$.

The presence of total coliforms is an indicator of faecal as well as post processing contamination and is reflective of unsanitary conditions practiced during the different stages of food production (Van Kessel et al., 2004). The assumption is that there is an association between the detection of faecal coliforms and pathogenic organisms (Van Kessel et al., 2004). Prevalence of coliforms contamination were $96.7 \%$, $73.3 \%$ and $90 \%$, while the average coliform counts were $6.55 \times 10^{4} ; 6.67 \times 10^{4}$ and $1.19 \times 10^{5}$ for whipped cream; chocolate pudding and sauce samples, respectively (Table 5). $19(65.5 \%) ; 11(50 \%)$ and 16 (59.3) of the positive examined samples of whipped cream; chocolate pudding and sauce had frequency distribution between $10^{4}-<10^{5} \mathrm{cfu} \mathrm{g}^{-1}$, respectively (Table 6).

Table 7 and 8 showed that yeasts and molds were counted in $66.7 \%$; $56.7 \%$ and $70 \%$ with average values / $\mathrm{g}$ of $1.41 \times 10^{3} ; 1.11 \times 10^{3}$ and $7.55 \times 10^{2}$ of whipped cream; chocolate pudding and sauce samples, respectively. Out of 20 positive examined whipped cream samples, $8(40 \%)$ had counts ranged from $10^{2}$ to $<10^{3}$. Yeasts and molds may grow over a wide range of temperature and gain entrance to milk either from the milk used, air contamination or utensils. So, their presence is indicative of unsatisfactory sanitation during processing and handling of the product. The high level of these microorganisms may be due to post pasteurization contamination.

None of examined whipped cream, chocolate pudding and sauce samples were positive for coagulase positive S. aureus (Table 9). S. aureus is considered the third most important cause of disease in the world amongst the reported food-borne illnesses (Zhang et al., 1998). This Gram-positive bacterium has no particular nutritional and environmental requirement for its growth and it can grow at an $\mathrm{pH}$ above 4.8 and its minimum growth temperature is $18-45^{\circ} \mathrm{C}$ (Scott, 1953 and Martin and Iandolo, 2000).

Three isolates of $E$. coli could be detected in the examined samples of whipped cream and sauce (2 and 1 isolates, respectively, Table 9), but Presumptive E. coli O157:H7 colonies (indole positive) did not confirmed serologically using antibodies to the $\mathrm{O} 157$ antigen. Since its identification as a human pathogen in1982 (Riley et al., 1983), E. coli O157:H7 has become a pathogen of major concern for the food and dairy industries because of its ability to cause severe illness such as haemorrhagic colitis (HC), haemolytic uremic syndrome (HUS), and thrombotic thrombocytopenic purpura (TTP). The diseases affect all age groups and the pathogen is exceptional in its severe consequences of infection, its low infectious dose and unusual acid resistance (Buchanan and Doyle, 1997). E. coli O157:H7 serotypes are identified as enterohemoragic E. coli and categorized in Shiga-like toxin producing E. coli (STEC) (Oksuz, et al., 2004). It causes haemorrhagic colitis, hemolytic-ureamic syndrom (HUS) and thrombotic thrombocytopenic purpura (TTP) (Zhao et al., 1998).

In addition to the previous indicator bacteria, investigation of L. monocytogenes was undertaken to examine the safety of dairy products and to determine the possibility of any potential health hazard. $L$. monocytogenes could be isolated from chocolate pudding in percentage of $26.7 \%$ (Table 9). The sources of L. monocytogenes in such products may be faecal and environmental contamination during milking, storage and transport, infected cows in dairy farms, poor silage quality and improper handling of these products at the points of sale (Sanaa et al., 1993 and Van Kessel et al., 2004). Lack of hygienic practices during the processing and production of these dairy-based products may also contribute to high levels of contamination. For example, crosscontamination may occur after heat treatment. Furthermore, various studies have indicated that certain strains of L. monocytogenes survive within the food processing environment (Unnerstad et al., 1996 and Senczek et al., 2000). The ability of $L$. monocytogenes to form biofilms (Harvey et al., 2007) may contribute to its persistence in food processing plants (Thimothe et al., 2004). The milk processing environment and handling practices change may vary among the processing plants. About $47 \%$ surface of hand of the food handlers and $16 \%$ on the processing tables were found to carry L. monocytogenes (Kerr et al., 1993 and Jeyasekaran et al., 1996).

\section{CONCLUSION}

Cross-contamination of foods is one of the major concerns in the food industry, and if microorganisms are not completely removed from food-contact surfaces, they may go on to form biofilms and also increase the bio-transfer potential. The presence of $L$. monocytogenes in a processing plant could lead to post-processing contamination, which also draws attention to the need to reduce the level of contamination of milk that will eventually be transported to a milk processing plant. The present study indicated the incidence of L. monocytogenes 
examined products processing plants which may possess a potential threat to public health.

In conclusion, this study demonstrates the presence of some pathogens including L. monocytogenes, and $E$. coli in dessert. Therefore, these foods are serious risk to the public health. Likewise, the presence of these organisms indicated that there were poor hygienic conditions during the manufacturing, storage and sales process of these two traditional foods. Manufacturing procedures within the scope of the HACCP, appropriate hygienic measures to avoid processing and post processing cross contamination and the use of pasteurized milk are critical for control of these pathogens in these foods.

\section{REFERENCES}

A.P.H.A. (1992): Standard Methods for the Examination of Dairy Products. $13^{\text {th }}$ Ed., American Public Health Association. Academic Press: 2062- 2065.

AOAC (1998): Bacteriological analytical manual. $8^{\text {th }}$ ed., Gaithersburg, WD, USA: AOAC International, Revision A.

Aygun, P and Pehlivanlar, S. (2006): Listeria spp. in the raw milk and dairy products in Antakya, Turkey. Food Control; 17: 599-682.

Baired-Parker, A. (1962): An improved diagnostic and selective medium for isolating Coagulase positive staphylococci. Journal of applied bacteriology, 25: 12-19.

Buchanan, R. and Doyle, M. (1997): Food borne disease significance of Escherichia coli O157: $\mathrm{H} 7$ and other enterohemorrhagic Escherichia coli. Food Tech., 5: 69-76.

Bullerman, L.B. (1980): Incidence of mycotoxic moulds in domestic and imported cheese. J. food safety, 2,1:47- 58. dairy Sci.abst. 42, 11: 7270 .

Burgess, S.A.; Lindsay, D. and Flint, S.H. (2010): Thermophilic bacilli and their importance in dairy processing. International Journal of Food Microbiology, 144, 2: 215-225.

CDC (2012): Center for Disease Control and Prevention, Reports of Selected E. coli Outbreak Investigations. Multistate Outbreak of Shiga Toxin-producing Escherichia coli O157:H7 Infections Linked to Organic Spinach and Spring Mix Blend.

Cocolin, L.; Rantsiou, K.; Iacumin, L.; Cantoni, C. and Comi, G. (2002): Direct identification in food samples of Listeria spp. and Listeria monocytogenes by molecular methods. Appl. Environ. Microbiol.; 68: 6273-82.

Danielsson-Tham, M.L.; Eriksson, E.; Helmersson, S.; Leffler, M.; Ludtke, L. and Steen, M. (2004): Causes behind a human cheese-borne outbreak of gastrointestinal listeriosis. Food borne Pathog. Dis., 1: 153-159.
De Wijk, R.A.; Van-Gemert, L.J.; Terpstra, M.E.J. and Wilkinson, C.L. (2003): Texture of semisolids, sensory and instrumental measurements on vanilla custard desserts. Food Qual. Prefer. 14: 305-317.

Dinges, M.; Orwin, P.M. and Schlievert, P.M. (2000): Exotoxins of Staphylococcus aureus. Clin. Microbiol. Rev., 13: 16-34.

Downes, F.P. and Ito, K. (2001): Compendium of methods for the microbiological examination of foods., $4^{\text {th }}$ Ed. Washington, DC: American Public Health Association.

Frank, J.F. and Yousef, A.E. (2004): Tests for Groups of Microorganisms., In: Standard Methods for the Examination of Dairy Products. H.M. Wehr and J.F. Frank, eds. American Public Health Assoc., Washington, D.C.: 227-247.

Frazier, W.C. and Westhoff, D.C. (1978): Food Microbiology, $3^{\text {rd }}$ Edition. Hill Publishing Co. New York.

Gilbert, R.J.; De Louvois, J.; Donovan, T.; Little, C.; Nye, K. and Ribeiro, C.D. (2000): Guidelines for the microbiological quality of some readyto-eat foods sampled at the point of sale., Commun Dis. Public Health, 3: 163-167.

Gillespie, I. and Little, C. (2000): Microbiological examination of cold ready-to-eat sliced meats from catering establishments in the United Kingdom. J Appl. Microbiol.; 88: 467-74.

Gilot, P. and Content, J. (2002): Specific identification of Listeria welshimeri and Listeria monocytogenes by PCR assays targeting a gene encoding a fibronectinbinding protein. J. Clin. Microbiol; 40:698703.

González-Tomás, L. and Costell, E. (2006): Relation between consumers' perception of color and texture of dairy desserts and instrumental measurements using generalized procrustes analysis. J. Dairy Sci. 89: 4511-4519.

Gulmez, M. and Guven, A. (2003): Survival of Escherichia coli O157:H7, Listeria monocytogenes $4 \mathrm{~b}$ and Yersenia enterocolitica $\mathrm{O} 3$ in different yogurt and kefir combinations as prefermentation contaminant. J Appl. Microbiol., 95: 632-6.

Harrigan, W.F. and McCance, M.E. (1976): Laboratory Methods in Food and Dairy Microbiology. Academic Press Inc., London.

Harvey, J.; Keenan, K.P. and Gilmour, A. (2007): Assessing biofilm formation by Listeria monocytogenes strains. Food Microbiology, 24: 380-392.

Herman, L.; De Block, J. and Moermans, R. (1995): Direct detection of Listeria monocytogenes in 25 milliliters of raw milk by a two-step PCR with nested primers. Appl. Environ. Microbiol; 61:817-9.

Hitchins, A.D. (1995): Listeria monocytogenes. Food and Drug Administration Bacteriological 
Analytical Manual. $8^{\text {th }}$ edition. AOAC: $1001-$ 1013.

Holmberg, S.D. and Blake, P.A. (1984): Staphylococcal food poisoning in the United States: new facts and old misconceptions. JAMA, 251: 487-489.

Horwitz, W. (2001): Official Methods of Analysis of AOAC International, $17^{\text {th }}$ Edn. Gaithersburg, MD: AOAC International, 2000.

Jay, J.M. (1978): Modern Food Microbiology, $2^{\text {nd }}$ Ed.D. Van Nostrand Company, New York.

Jeyasekaran, G.; Karunasagar, I. and Karunasagar, I. (1996): Incidence of Listeria spp. in tropical fish. International Journal Food Microbiology, 31: 333-340.

Kells, J. and Gilmour, A. (2004): Incidence of Listeria monocytogenes in two milk processing environments and assessment of Listeria monocytogenes blood agar for isolation. Int. J. Food Microbiol., 91: 167-74.

Kerr, K.G.; Birkenhead, D.; Seale, K.; Major, J. and Hawkey, P.M. (1993): Prevalence of Listeria spp. on the hands of good workers. Journal of Food Protection, 56: 525-527.

MacDonald, P.D.; Whitwam, R.E.; Boggs, J.D.; MacCormack, J.N.; Anderson, K.L. and Reardon, J.W. (2005): Outbreak of Listeriosis among Mexican immigrants as a result of consumption of illicitly produced Mexicanstyle cheese. Clin. Infect. Dis., 40: 677-82.

Makino, S.I.; Kawamoto, K.; Takeshi, K.; Okada, Y.; Yamasaki, M. and Yamamoto, S. (2005): An outbreak of food-borne Listeriosis due to cheese in Japan, during 2001. Int. J. Food Microbiol., 104: 189-96.

Manfreda, G.; De Cesare, A.; Stella, S.; Cozzi, M. and Cantoni, C. (2005): Occurrence and ribotypes of Listeria monocytogenes in Gorgonzolla cheese. Int. J. Food Microbiol., 102: 287-93.

Martin, S.E. and Iandolo, J.J. (2000): Staphylococcus. In: Robinson, R.K.; Batt, C.A.; Patel, P.D. Eds., Encyclopedia of Food Microbiology. Academic Press: 2062- 2065.

McLauchlin, J.; Mitchell, R.; Smerdon, W. and Jewell, K. (2004): Listeria monocytogenes and Listeriosis: a review of hazard characterisation for use in microbiological risk assessment of foods. Int. J. Food Microbiol., 92: 15-33.

Meyer-Broseta, S.; Diot, A.; Bastian, S. and RiviereCerf, O. (2003): Estimation of low bacterial concentration: Listeria monocytogenes in raw milk. Int. J. Food. Microbiol.: 80: 115.

Mossel, D.A.A. (1982): Microbiology of Foods. $3^{\text {rd }}$ Ed., the Univ. of Utrecht, Netherlands ISBN.

Oksuz, O.; Arici, M.; Kurultay, S. and Gumus, T. (2004): Incidence of Escherichia coli 0157 in raw milk and white pickled cheese manufactured from raw milk in Turkey. Food Control, 15: 453-456.
Okwumabua, O.; O'Connor, M.; Shull, E.; Strelow, K.; Hamacher, M. and Kurzynski, T. (2005): Characterization of Listeria monocytogenes isolates from food animal clinical cases: PFGE pattern similarity to strains from human listeriosis cases. FEMS Microbiol. Lett, 249: 275-81.

Oliver, S.P.; Jayarao, B.M. and Almeida, R.A. (2005): Food-borne pathogens in milk and the dairy farm environment: food safety and public health implications. Foodborne Pathog. Dis., 2:115.

Osamwonyi, O.U. (2005): Occurrence of coliforms in ice cream. Dept. of Microbiology, University of Benin. Bs.c Thesis: 65.

Peng, H. and Shelef, L. (2000): Rapid detection of low levels of Listeria in foods and next-day confirmation of L. monocytogenes. J Microbiol Methods, 41:113-20.Qual. Prefer. 14: 305-317.

Ray, B. and Speck, M.L. (1978): Plating procedure for the enumeration of coliforms from dairy products. Appl. and Enviroment., 35(4): 820822.

Riley, L.W.; Remis, R.S.; Helgerson, S.D.; McGee, H.B.; Wells, J.G.; Davis, B.R.; Hebert, R.J.; Olcott, E.S.; Johnson, L.M.; Hargrett, N.T.; Blake, P.A. and Cohen, M.L. (1983): Hemorrhagic colitis associated with a rare Escherichia colisero-type. $N$ Engl. J. Med. 308: 681-685.

Saleh, I.; Zouhairi, O.; Alwan, N.; Hawi, A.; Barbour, E. and Harakeh, S. (2009): Antimicrobial resistance and pathogenicity of Escherichia coli isolated from common dairy products in the Lebanon. Ann. Trop. Med. Parasitol, 103: 39-52.

Sanaa, M.; Poutrel, B.; Menard, J.L. and Serieys, F. (1993): Risk factors associated with contamination of raw milk by Listeria monocytogenes in dairy farms. J. Dairy Sci, 76: 2891-8.

Scott, W.J. (1953): Water relations of Staphylococcus aureus at 30 jC. Aust. J. Biol. Sci 6: 549-564.

Senczek, D.; Stephan, R. and Untermann, F. (2000): Pulsed-field gel electrophoresis (PFGE) typing of Listeria strains isolated from a meat processing plant over a 2-year period. International Journal of Food Microbiology, 62: 155-159.

Siegman-Igra, Y.; Levin, R.; Weinberger, M.; Golan, Y.; Schwartz, D. and Samra, Z. (2002): Listeria monocytogenes infection in Israel and review of cases worldwide. Emerg. Infect. Dis., 8: 305-10.

Thimothe, J.; Nightingale, K.K.; Gall, K.; Scott, V.N. and Wiedmann, M. (2004): Tracking of Listeria monocytogenes in smoked fish processing plants. J. of Food Protection, 67: 328-341. 
U.S. Dairy Export Council (2001): An overview of changes in the characteristics, functionality and nutritional value of skim milk powder (SMP) during storage. http://usdec.files.cms plus.com/PDFs/FoodAid/SMPStorageFactShe et.pdf.

Unnerstad, H.; Bannerman, E.; Bille, J.; DanielssonTham, M.L.; Waak, E. and Tham, W. (1996): Prolonged contamination of a dairy with Listeria monocytogenes. Netherland Milk and Dairy Journal, 50: 493-499.

Van Kessel, J.S.; Karns, J.S.; Gorski, L.; McCluskey, B.J.; Perdue, M.L. (2004): Prevalence of Salmonella, Listeria monocytogenes, and faecal coliforms in bulk tank milk on US dairies. J Dairy Sci, 8: 2822-30.

Vela, A.; Fernandez-GarayzáBal, J.; Latre, M.; Rodriguez, A.; Dominguez, L. and Moreno, M. (2001): Antimicrobial susceptibility of
Listeria monocytogenes isolated from meningoencephalitis in sheep. Int. J. Antimicrob. Agents, 17: 215-20.

Zhang, S.; Iandolo, J. and Stewart, C. (1998): The enterotoxin D plasmid of Staphylococcus aureus encodes a second enterotoxin determinant (sej). FEMS Microbiol. Lett. 168: 227-233.

Zhao, T.; Doyle, M.P.; Harmon, B.G.; Brown, C.A.; Eric Mueller, P.O. and Parks, A.H. (1998): Reduction of carriage of Enterohemorrhagic Escherichia coli O157:H7 in cattle by inoculation with probiotic bacteria. J. Clin. Microbiol., 36: 641-647.

Zhou, X. and Jiao, X. (2002): Polymerase chain reaction detection of Listeria monocytogenes using oligonucleotide primers targeting actA gene. Food Control, 16: 125-30.

\section{الفحوصات الميكروبيولوجية لبعض الخلطات المجفة من الحلويات اللبنية المباعة في مدينة أسيوط \\ مروة محمد نبيل الجندي ، لمباء محد طلعت علي}

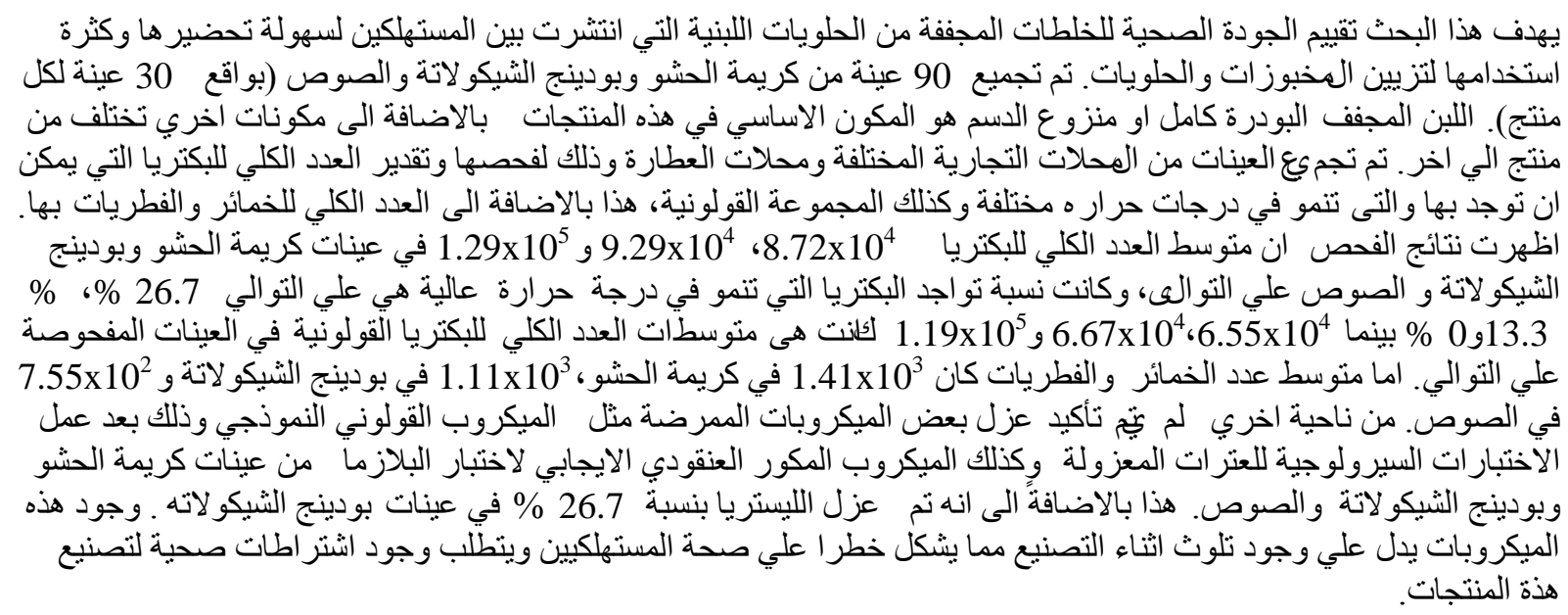

